\begin{tabular}{|c|c|c|c|}
\hline \multirow{3}{*}{$\begin{array}{r}\text { Case Reports in } \\
\text { Gastroenterology }\end{array}$} & \multicolumn{2}{|c|}{ Case Rep Gastroenterol 2018;12:344-351 } & \multirow[b]{2}{*}{$\begin{array}{l}\text { Karger } \\
\text { Open'access }\end{array}$} \\
\hline & $\begin{array}{l}\text { DOI: 10.1159/000490098 } \\
\text { Published online: June 28, } 2018\end{array}$ & $\begin{array}{l}\text { (c) } 2018 \text { The Author(s) } \\
\text { Published by S. Karger AG, Basel } \\
\text { www.karger.com/crg }\end{array}$ & \\
\hline & $\begin{array}{l}\text { This article is licensed under } \\
\text { International License (CC BY-N } \\
\text { Usage and distribution for comm }\end{array}$ & $\begin{array}{l}\text { nons Attribution-NonCommercial } 4.0 \\
\text { ger.com/Services/OpenAccessLicense) } \\
\text { uires written permission. }\end{array}$ & \\
\hline
\end{tabular}

\title{
En Bloc Endoscopic Resection of Large Pedunculated Brunner's Gland Hamartoma: A Case Report
}

\author{
Annalisa Pasetti ${ }^{a}$ Elvira Capoferro ${ }^{b}$ Giulia Querzoli ${ }^{c}$ Renzo Montanari ${ }^{b}$ \\ Paolo Bocus ${ }^{b}$ \\ ${ }^{a}$ Gastroenterology Unit, Department of Life, Health and Environmental Sciences, \\ University of L'Aquila, L'Aquila, Italy; ${ }^{b}$ Gastroenterology and Digestive Endoscopy Unit, \\ Sacro Cuore Don Calabria Hospital of Negrar, Negrar, Italy; 'Pathology Unit, Sacro Cuore \\ Don Calabria Hospital of Negrar, Negrar, Italy
}

\section{Keywords}

Brunner hamartoma $\cdot$ Gastrointestinal hemorrhage $\cdot$ En bloc endoscopic resection

\begin{abstract}
Brunner's gland hamartoma (BGH) is an uncommon benign tumor arising from alkaline-based mucin-secreting glands of the duodenum. These lesions are typically discovered incidentally during upper gastrointestinal endoscopy or radiological diagnostics, even though they can eventually lead (in the case of increasing size) to obstructive or hemorrhagic symptoms. We report the case of a 67-year-old Caucasian man with two episodes of melena and epigastric pain during the last month. Esophagogastroduodenoscopy revealed a large pedunculated and eroded polyp inside the antrum with a $2-\mathrm{cm}$-long stalk arising from the anterior wall of the duodenal bulb. Endoscopic ultrasonography showed a submucosal lesion with homogeneous hyperechoic parietal thickening and some central gaps. The muscularis was undamaged. No lymphadenopathy was observed. We performed an en bloc endoscopic resection of the polyp. The size of the whole piece was approximately $6 \times 3 \times 2 \mathrm{~cm}$, pseudocapsulated and tough in consistency. In the case presented, the en bloc endoscopic removal was successful despite the size of the tumor.

(C) 2018 The Author(s)

Published by S. Karger AG, Basel
\end{abstract}




\section{Introduction}

Brunner's gland hamartoma (BGH), also known as Brunneroma or Brunner's gland adenoma, is an uncommon benign tumor arising from alkaline-based mucin-secreting glands of the duodenum [1]. These lesions account for $10 \%$ of benign tumors of the duodenum [2]. BGHs are predominantly found in the duodenal bulb (57\%) with decreasing frequency in the second $(27 \%)$ and third parts $(5 \%)$ of the duodenum. This distribution corresponds to the anatomical distribution of Brunner's glands [3]. They secrete an alkaline fluid of mucin as well as pepsinogen and urogastrone, which protect the epithelium from and inhibits secretion of gastric chyme, respectively [4-6]. BGHs are most prevalent in the fifth and sixth decades and represent genders and race equally $[5,6]$. These lesions are typically discovered incidentally and during upper gastrointestinal endoscopy or radiological diagnostics, even though they can eventually lead (in the case of increasing size) to obstructive or hemorrhagic symptoms such as abdominal pain, nausea, dyspepsia, vomiting, intussusception, upper gastrointestinal bleeding, and recurrent pancreatitis [7].

\section{Case Report}

A 67-year-old Caucasian man came to our hospital for a second opinion because a surgical resection was proposed to him at the time of first esophagogastroduodenoscopy (EGD) performed in another hospital. One month before, he had two episodes of melena accompanied by epigastric pain for which he went to the nearest emergency room. There he had an EGD performed that showed a big polyp of the duodenum to be surgically removed. When the patient came to us, he was in good health, he was only under chronic antihypertensive therapy, and transfusions were not necessary for the previous episode of melena. He denied nonsteroidal anti-inflammatory drugs abuse. The new EGD revealed a large pedunculated polyp with regular mucosa but with eroded apex, with a 2-cm-long stalk arising from the anterior wall of the duodenal bulb (Fig. 1) and spontaneously migrating between antrum and second duodenum. Endoscopic ultrasonography (EUS) performed with high-frequency mini-probe showed a submucosal lesion with homogeneous, hyperechoic parietal thickening, and some central gaps. The muscularis propria was undamaged. No lymphadenopathy was observed (Fig. 2). We proposed to the patient an endoscopic resection of the polyp to prevent other episodes of bleeding or obstruction, and he agreed. To perform the procedure in deep sedation and to promptly treat any complications, the patient was admitted to our gastroenterology ward. He underwent ECG and chest X-ray, which resulted normal. The anesthetic examination did not place any contraindications to anesthesia, the blood counts were in the normal range. The anesthesia was done with Diprivan and ketamine iv. The EGD confirmed that the polyp was attached to the anterior wall of the bulb immediately downstream of the pyloric ring. Resection was made en bloc by positioning a diathermic loop at the base of the polyp from the stomach. The size of the polyp, which was located inside the duodenal bulb, made the procedure challenging at the time of the scheduled EGD; therefore, we decided to pull it up into the stomach and cut the stalk from this position (Fig. 3). A plastic cap was used to obtain a stable position of the scope inside the pylorus. There was no bleeding from the resected section, and there were no visible blood vessels (Fig. 4). No complication occurred, the polyp was recovered through a Basket Polyp Retriever and sent for histological analysis (Fig. 5). When the patient 


\section{Case Reports in Gastroenterology}

Case Rep Gastroenterol 2018;12:344-351

DOI: 10.1159/000490098

(c) 2018 The Author(s). Published by S. Karger AG, Basel www.karger.com/crg

Pasetti et al.: En Bloc Endoscopic Resection of Large Pedunculated Brunner's Gland Hamartoma: A Case Report

was brought back in the ward, he was conscious and did not complain of pain. His blood pressure was $120 / 80 \mathrm{~mm} \mathrm{Hg}$, saturation $98 \%$, and heart rate 54 . He fasted for $24 \mathrm{~h}$ and underwent infusion therapy with proton pump inhibitors at maximum dosage and hydration.

The size of the whole piece was approximately $6 \times 3 \times 2 \mathrm{~cm}$, pseudocapsulated and tough in consistency. The gross endoscopic resection specimen showed a well-defined yellow-white solid mass lined by a normal duodenal mucosa measuring $6 \times 3 \times 2 \mathrm{~cm}$ (Fig. 6). The histological examination showed nodular physiognomy of Brunner glands with ductular structures and epithelial coating and without significant atypia and scattered stromal elements in the submucosa (Fig. 7). This morphological picture is compatible with BGH (Fig. 8).

\section{Discussion}

BGH was described for the first time by Johann Conrad Brunner (1653-1727) in 1688. He was a Swiss anatomist who gave a precise anatomic description of the duodenal submucosal glands and coined the term "pancreas secondarium." These glands are branching acinotubular glands that arise in the duodenum submucosa. In 1934, Feyter proposed a classification of the abnormal proliferation of Brunner's glands into three different subsets: type 1, diffuse nodular hyperplasia; type 2, circumscribed nodular hyperplasia; and type 3, glandular adenoma [8]. According to this classification, the diagnosis of BGH is based on histological features, such as lack of surfacing capsule, network combination of acini, smooth muscle, adipose tissue, Paneth cells and mucosal glands, and mostly a lack of cellular atypia [9]. The pathogenesis of BGH is still unknown, but there are some hypotheses. Three of the most quoted are as follows: hyperchlorhydria-like trigger of disease, correlation to pancreatic diseases, and inflammation [1012]. Most patients are asymptomatic, but some may present with nonspecific symptoms, such as abdominal bloating, abdominal pain, or nausea, and other patients may present with hemorrhage or obstruction. EUS is specifically useful in evaluating extension, morphological characteristics and the vascularity of BGH [13]. The CT scan is a second-line study that permits the physician to analyze the extent of BGH and its relationship with adjacent structures [14]. The differential diagnosis of duodenal growth includes leiomyomas, adenomas, lipomas, adenocarcinomas, carcinoid tumors, lymphomas, leiomyosarcoma, pancreatic or ampullary tumors, and the lesions of Peutz-Jeghers syndrome $[15,16]$.

Because upper endoscopic biopsies usually fail, an accurate study using EUS and, if necessary, CT scan is mandatory to study the extension, morphological characteristics, and vascularity of the lesion. In particular, the position in the duodenum, dimensions, and invasion of muscularis propria are the three fundamental elements when deciding whether to do an endoscopic or surgical resection. Endoscopic polypectomy is the suggested treatment for duodenal lesions occupying the first part of the duodenum, whereas more aggressive treatment has been reported in the case of D2 or D3 BGH localization. Endoscopic resection is indicated for the removal of pedunculated polyps. Regarding acceptable size, some things have changed compared to the past - now a safe endoscopic resection is possible also for lesions measuring more than $3 \mathrm{~cm}$. This is possible thanks to advanced endoscopic techniques and to a careful study of the morphological characteristics of the lesion. In our case, the polyp was pedunculated, did not invade the muscularis propria, and satellite lymphadenopathies were absent, which suggested a benign nature of the lesion. Endoscopy resection in selected cases prevents demolition surgery. Treatment choice depends on tumor size, symptoms, and malignancy. Endoscopic treatment is preferred for pedunculated lesions, whereas surgical resection is man- 
Pasetti et al.: En Bloc Endoscopic Resection of Large Pedunculated Brunner's Gland Hamartoma: A Case Report

datory in the presence of malignancy or if endoscopic methods fail. Asymptomatic lesions usually have low neoplastic potential, and therefore, they only require a follow-up. In the case presented, en bloc endoscopic removal was successful despite the size of the tumor.

\section{Statement of Ethics}

The study was reviewed and approved by the Comitato Etico of Sacro Cuore Don Calabria Hospital of Negrar Institutional Review Board.

\section{Disclosure Statement}

The study participant provided informed consent prior to study enrollment.

\section{Author Contributions}

P.B. and E.C. designed and performed the work. E.C., G.Q., and R.M. contributed to the drafting. A.P. wrote the paper.

\section{References}

1 Nakabori T, Shinzaki S, Yamada T, Nishida T, Iijima H, Tsujii M, et al. Atypical duodenal ulcer and invagination caused by a large pedunculated duodenal Brunner's gland hamartoma [PMID: 24368074 DOI: 10.1016/j.gie.2013.11.002]. Gastrointest Endosc. 2014 Apr;79(4):679-80.

2 Chattopadhyay P, Kundu AK, Bhattacharyya S, Bandyopadhyay A. Diffuse nodular hyperplasia of Brunner's gland presenting as upper gastrointestinal haemorrhage [PMID: 18204775]. Singapore Med J. 2008 Jan;49(1):81-3.

3 Kostalas M, Jackson P, Karanjia N. Brunner's gland hamartoma: a cause of the double-duct sign [PMID: 27055413 DOI: 10.1308/rcsann.2016.0131]. Ann R Coll Surg Engl. 2016 Jul;98(6):e92-3.

4 Abbass R, Al-Kawas FH. Brunner gland hamartoma [PMID: 21960922 PMCID: PMC3096129]. Gastroenterol Hepatol (N Y). 2008 Jul;4(7):473-5.

5 de Nes LC, Ouwehand F, Peters SH, Boom MJ. A large Brunner's gland hamartoma causing gastrointestinal bleeding and obstruction [PMID: 18025785 DOI: 10.1159/111075]. Dig Surg. 2007;24(6):450-2.

6 Gokhale U, Pillai GR. Large Brunner's gland hamartoma: a case report [PMID: 22303509 DOI: 10.5001/omj.2009.11]. Oman Med J. 2009 Jan;24(1):41-3.

7 Jansen JM, Stuifbergen WN, van Milligen de Wit AW. Endoscopic resection of a large Brunner's gland adenoma [PMID: 12365469]. Neth J Med. 2002 Jul;60(6):253-5.

8 Goldman RL. Hamartomatous polyp of Brunner's glands [PMID: 13948780]. Gastroenterology. 1963 Jan;44:57-62.

9 Peloso A, Viganò J, Vanoli A, Dominioni T, Zonta S, Bugada D, et al. Saving from unnecessary pancreaticoduodenectomy. Brunner's gland hamartoma: case report on a rare duodenal lesion and exhaustive literature review [PMID: 28408987 DOI: 10.1016/j.amsu.2017.03.034]. Ann Med Surg (Lond). 2017 Mar; 17:43-9.

10 Zangara J, Kushner H, Drachenberg C. daly B., Flowers J., Fantry G. Iron deficiency anemia due to a Brunner gland hamartoma [PMID: 9855270]. J Clin Gastroenterol. 1998;27(4):353-6.

11 Abbass R, Al-Kawas FH. Brunner gland hamartoma [ PMID: 21960922]. Gastroenterol Hepatol (N Y). 2008 Jul;4(7):473-5.

12 Stolte M, Schwabe H, Prestele H. Relationship between diseases of the pancreas and hyperplasia of Brunner's glands [PMID: 7336574]. Virchows Arch A Pathol Anat Histol. 1981;394(1-2):75-87.

13 Hizawa K, Iwai K, Esaki M, Suekane H, Inuzuka S, Matsumoto T, et al. Endosonographic features of Brunner's gland hamartomas which were subsequently resected endoscopically [PMID: 12471538 DOI: 10.1055/s2002-35849]. Endoscopy. 2002 Dec;34(12):956-8. 


\section{Case Reports in Gastroenterology}

\begin{tabular}{l|l}
\hline Case Rep Gastroenterol 2018;12:344-351 \\
\hline DOI: 10.1159/000490098 & $\begin{array}{l}\text { c 2018 The Author(s). Published by S. Karger AG, Basel } \\
\text { www.karger.com/crg }\end{array}$ \\
\hline
\end{tabular}

Pasetti et al.: En Bloc Endoscopic Resection of Large Pedunculated Brunner's Gland Hamartoma: A Case Report

14 Hur S, Han JK, Kim MA, Bae JM, Choi BI. Brunner's gland hamartoma: computed tomographic findings with histopathologic correlation in 9 cases [PMID: 20657222 DOI: 10.1097/RCT.0b013e3181d472dc]. J Comput Assist Tomogr. 2010 Jul;34(4):543-7.

15 Sen R, Gupta V, Sharma N, Chawla N, Kumar S, Malik S. Brunner gland hamartoma masquerading as malignancy; a rare case report [PMID: 25349687]. Middle East J Dig Dis. 2014 Oct;6(4):237-40.

16 Gaspar JP, Stelow EB, Wang AY. Approach to the endoscopic resection of duodenal lesions [PMID: 26811610 PMCID DOI: 10.3748/wjg.v22.i2.600 ]. World J Gastroenterol. 2016 Jan;22(2):600-17.

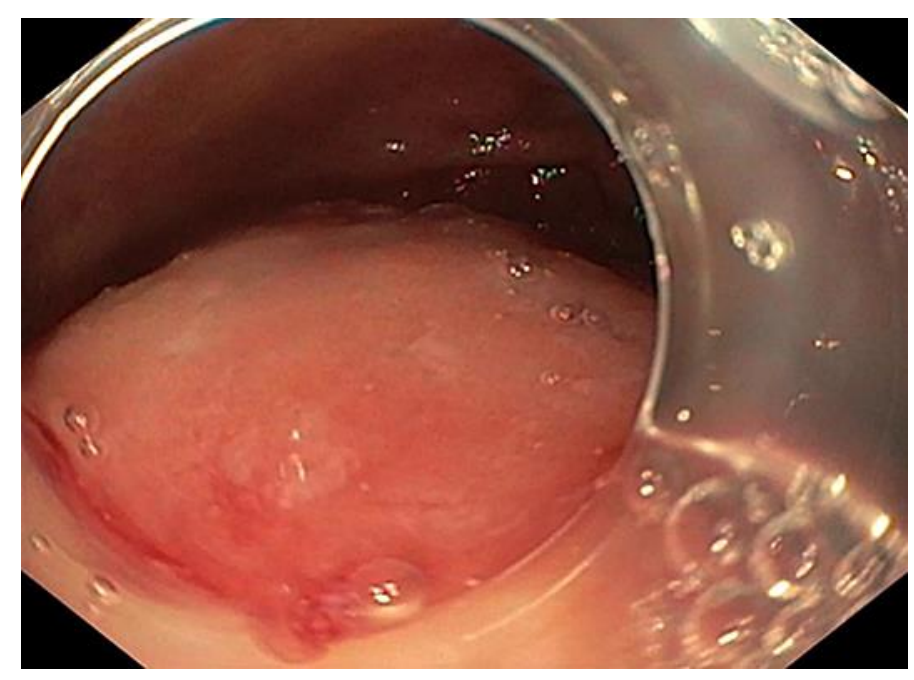

Fig. 1. Endoscopic view of a large duodenal polyp inside the bulb.

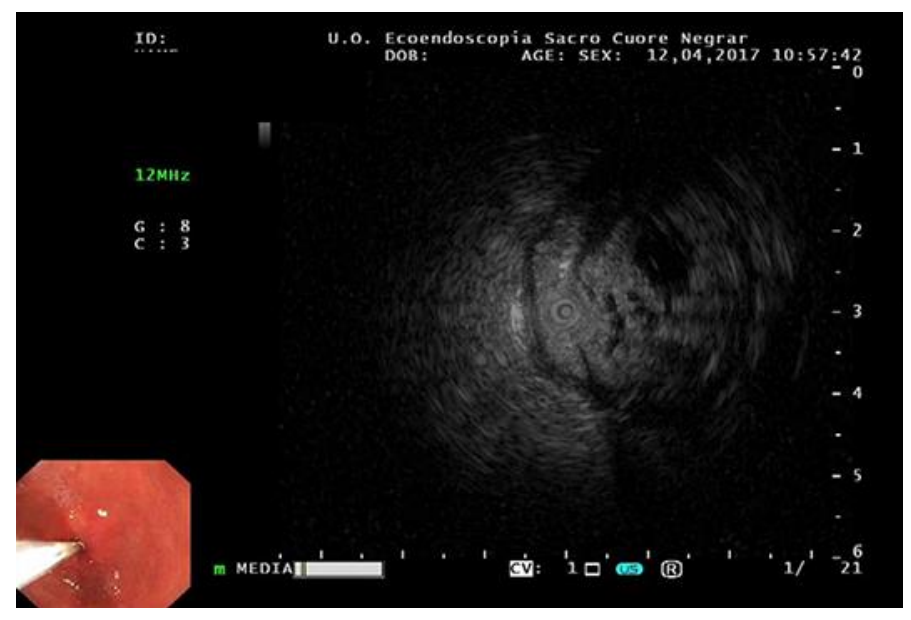

Fig. 2. Endosonographic view (Olympus 12-MHz EUS miniprobes under water). The polyp seems to originate from the submucosa without affecting the muscularis layer. 


\section{Case Reports in Gastroenterology}

\begin{tabular}{l|l}
\hline Case Rep Gastroenterol 2018;12:344-351 \\
\hline DOI: 10.1159/000490098 & $\begin{array}{l}\text { (c) 2018 The Author(s). Published by S. Karger AG, Basel } \\
\text { www.karger.com/crg }\end{array}$ \\
\hline
\end{tabular}

Pasetti et al.: En Bloc Endoscopic Resection of Large Pedunculated Brunner's Gland Hamartoma: A Case Report

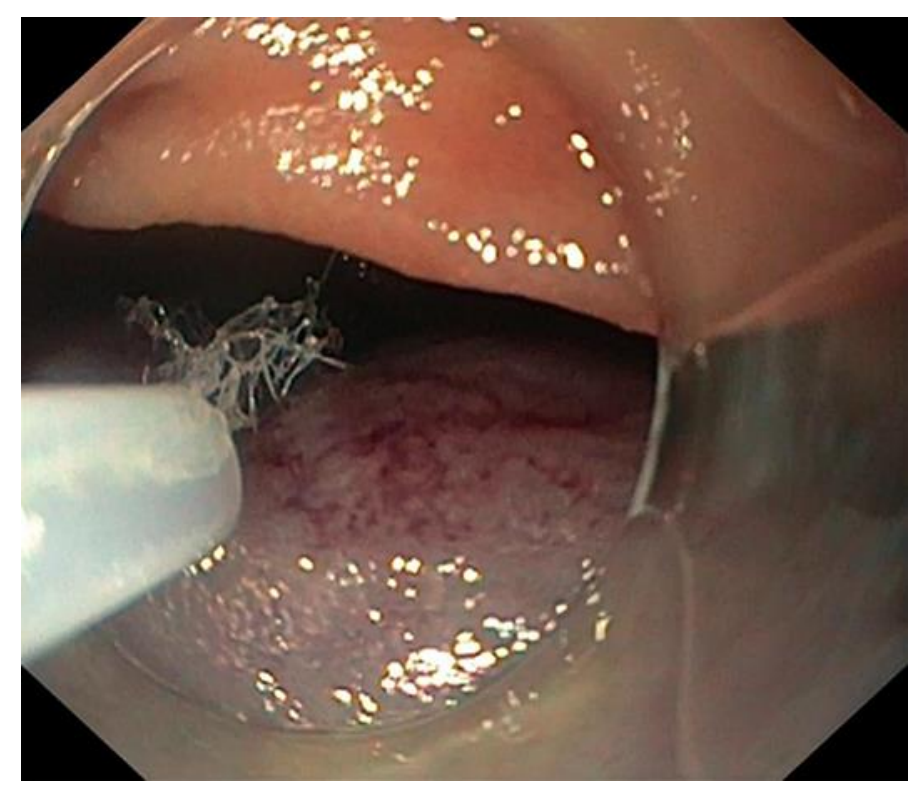

Fig. 3. The appearance of the newly resected polyp.

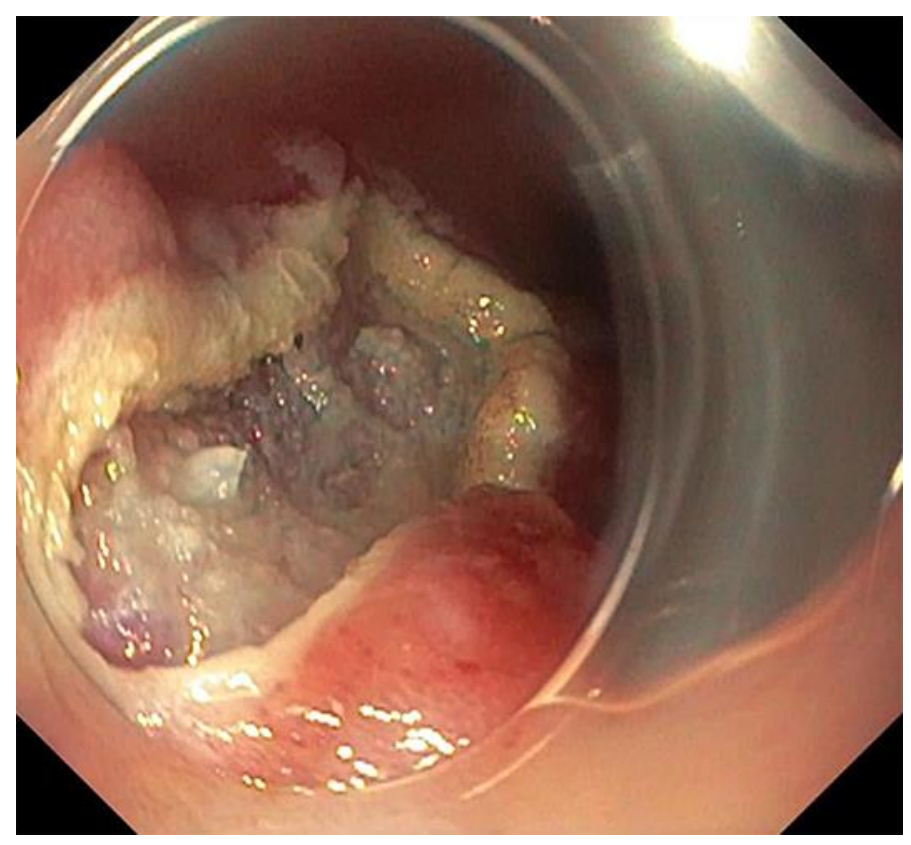

Fig. 4. Base of the polyp resection in the duodenal bulb. 


\section{Case Reports in Gastroenterology}

\begin{tabular}{l|l}
\hline Case Rep Gastroenterol 2018;12:344-351 \\
\hline DOI: 10.1159/000490098 & $\begin{array}{l}\text { c 2018 The Author(s). Published by S. Karger AG, Basel } \\
\text { www.karger.com/crg }\end{array}$ \\
\hline
\end{tabular}

Pasetti et al.: En Bloc Endoscopic Resection of Large Pedunculated Brunner's Gland Hamartoma: A Case Report

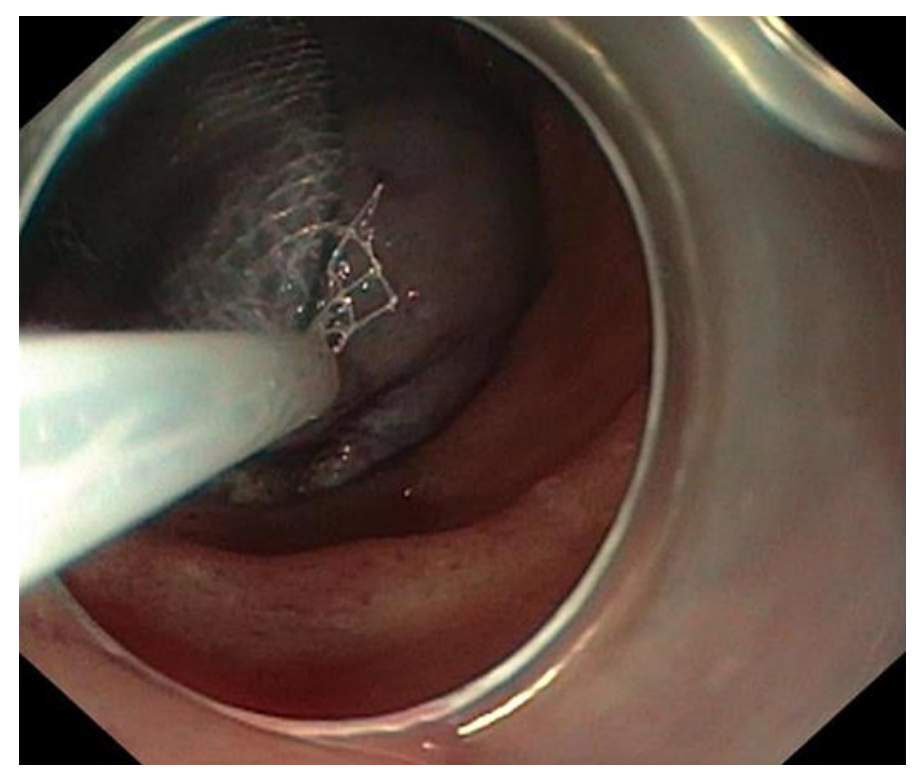

Fig. 5. The polyp is recovered by means of the Memory Basket Polyp Retriever.

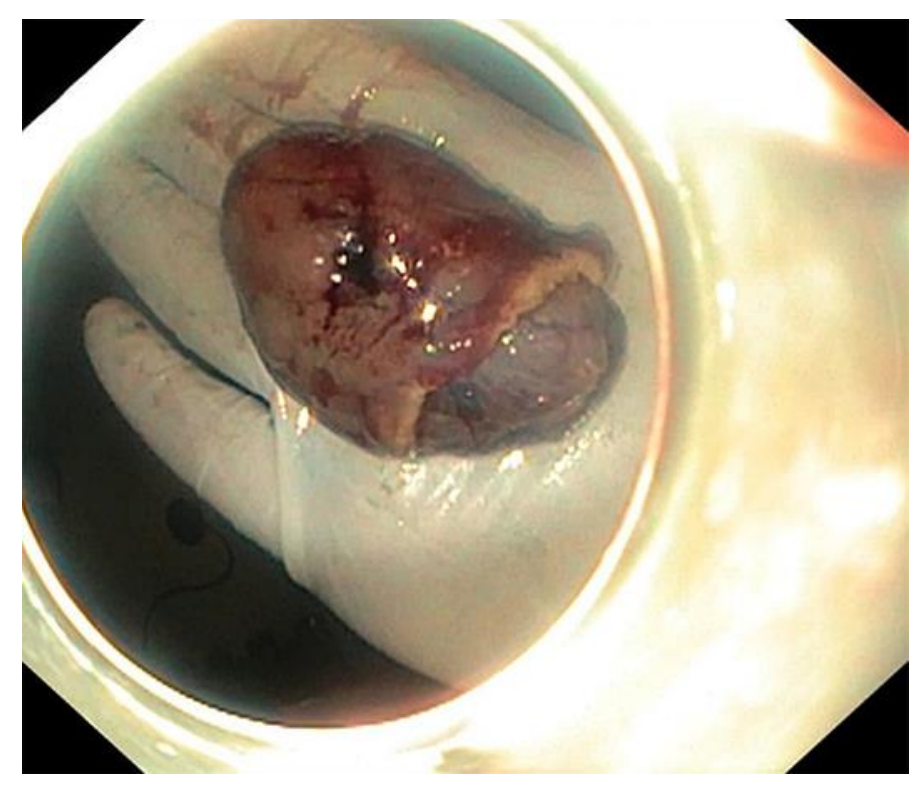

Fig. 6. The resected specimen in the operator's hand. The dimensions were $6 \times 3 \times 2 \mathrm{~cm}$. 


\section{Case Reports in Gastroenterology}

\begin{tabular}{l|l}
\hline Case Rep Gastroenterol 2018;12:344-351 \\
\hline DOI: 10.1159/000490098 & $\begin{array}{l}\text { @ 2018 The Author(s). Published by S. Karger AG, Basel } \\
\text { www.karger.com/crg }\end{array}$ \\
\hline
\end{tabular}

Pasetti et al.: En Bloc Endoscopic Resection of Large Pedunculated Brunner's Gland Hamartoma: A Case Report

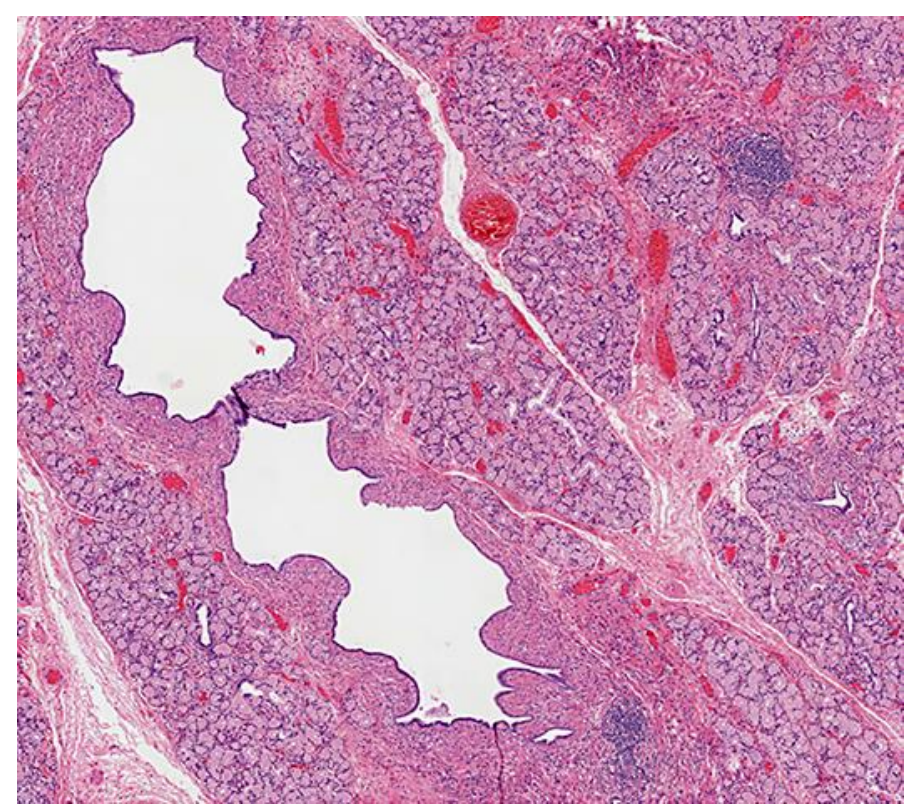

Fig. 7. Dilated ducts with some structural irregularity and cuboidal cells with scant cytoplasm are present in this sclerotic glandular focus, which retained a lobular architecture. Note the bland cytology with absent mitotic activity. HE. $\times 10$.

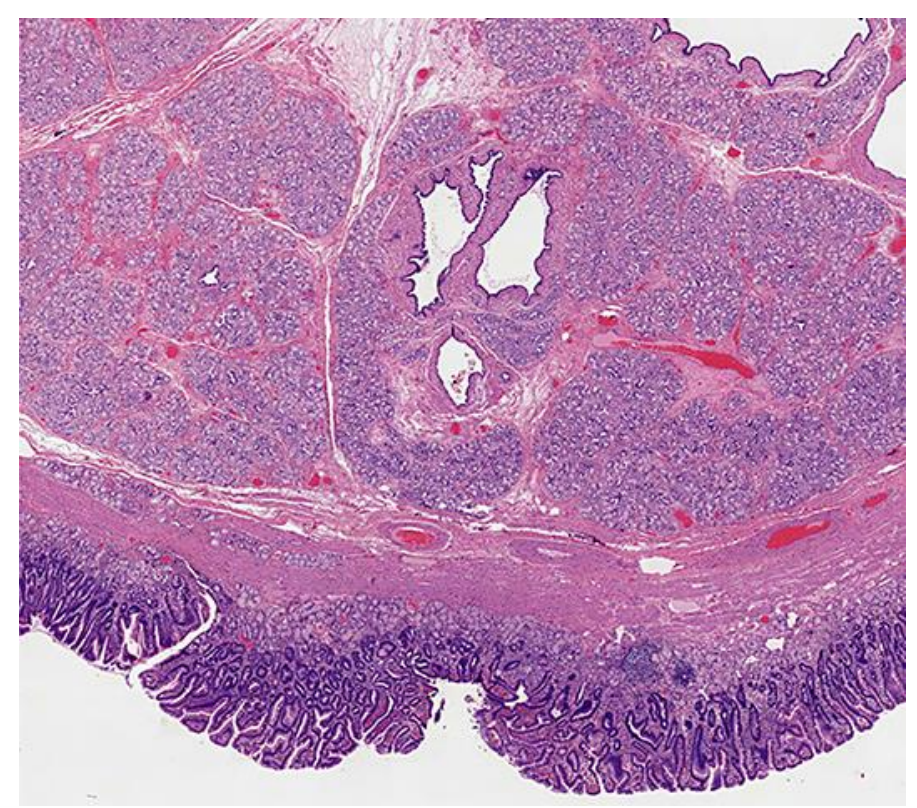

Fig. 8. Histological examination shows a submucosa proliferation of Brunner's glands in a lobulated pattern with dilated ducts and fibrous septa. HE. $\times 4$. 